\title{
ОСНОВНЫЕ НАПРАВЛЕНИЯ НАУЧНО-ТЕХНИЧЕСКОГО РАЗВИТИЯ В СЕЛЬСКОМ ХОЗЯЙСТВЕ ВЬЕТНАМА
}

\author{
(c) 2018 Нгуен Тхи Хыонг Май \\ аспирант \\ Академия труда и социальных отношений \\ 119454, г. Москва, ул. Лобачевского, д. 90 \\ E-mail:mainth@dhcd.edu.vn
}

\begin{abstract}
Сельское хозяйство занимает такое же важное место и с каждым днём укрепляет свою позицию в мировой экономике. Для Вьетнама сельское хозяйство сельская местность всегда занимало особенно важное место в истории развитии экономики страны в военное и мирное время. Это место становится все заметнее при индустриализации и модернизации страны. Однако, из-за социально-экономических особенностей вьетнамской экономики, до сих пор сельское хозяйство страны является монокультурным служит лишь самообеспечения. Производительность труда, коэффициент использования территории, продуктивность культурных растений и скота остаются низкими; качество сельскохозяйственной продукции недостаточно отвечает требованиям внутреннего и мирового рынка в условиях высокой конкурентоспособности. Поэтому для того, чтобы развивать сельское хозяйство Вьетнама по направлению роста его товарности, нужны подходящие, единые и эффективные способы решения. Среди них наука и технология являются движущей силой для развития сельского хозяйства Вьетнама.
\end{abstract}

Ключевые слова: экономика, сельское хозяйство, научно-технологический прогресс, производительность труда, товар сельскохозяйственного производства.

Для Вьетнама сельское хозяйство сельская местность всегда занимала особенно важное место в истории развитии экономики страны и в военное, и в мирное время. Это место становится все заметнее в индустриализации и модернизации страны.

Применение научных и технологических знаний в сельскохозяйственном производстве как необходимое требование для развития сельского хозяйства во Вьетнаме

В годы реформы, сельское хозяйство Вьетнама достигло особенно важных результатов, которые значительным фактором в поддержании стабильности и социально-экономического развития страны и в то же время утверждают важное место сельского хозяйства в индустриализации, модернизации страны.

Однако, из-за социально-экономических особенностей вьетнамской экономики, до сих пор сельское хозяйство страны всё остается монокультурным и может лишь служить для самообеспечения. Производительность труда, коэффициент использования территории, продуктивность культурных растений и скота остаются низкими; качество сельскохозяйственной продукции недостаточно отвечает требованиям внутреннего и мирового рынка в условиях высокой конкурентоспособности. В то же время для нашего сельского хозяйства характерны определенные противоречия и трудности.

Площадь сельскохозяйственных земель, основные оборудование для сельскохозяйственного производства уменьшаются в ходе индустриализации.

В настоящее время, когда площадь сельскохозяйственных земель постепенно уменьшается. Вьетнам является одной из тех стран, где плотность фрагментарных сельскохозяйственных земель остаётся высокой по сравнению с другими странами в регионе и в мире. В среднем площадь сельскохозяйственных земель на одного человека: в мире - 0,52 га/чел., в регионе Юго-Восточной Азии $-0,36$ га/чел., во Вьетнаме $-0,25$ га/чел. [1]. В ближайшее время с увеличением численности населения и уменьшением площади сельскохозяйственных земель, средняя площадь сельскохозяйственных земель на одного человека становится ещё меньше.

Темпы роста населения и избытка рабочей силы в сельской местности высоки. По данным исследования, в данный момент в деревнях примерно 30\% трудящихся, не имеющих работу [2. с.149]. Эта ситуация углубляется с каждым 
годом, так как темпы роста населения остаются высокими (выше 2\% процентов в год). В это время, как известно, площадь сельскохозяйственных земель ограничена, количество профессии в деревнях медленно увеличивается, промышленные зоны и услуги в городах недостаточно привлекательны для избыточного количества трудящихся.

Инфраструктура в сельской местности развивается слабо. Рынок сельского хозяйства и сельской местности медленно развивается, поэтому не может отвечать требованиям развития сельского хозяйства по направлению, специализированному на производстве товаров.

Быстрое истощение природных ресурсов и ухудшение экологической ситуации, загрязнение окружающей среды представляют собой большую угрозу для устойчивого и стабильного развития сельского хозяйства нашей страны. Через 30 лет после реформы духовная и материальная жизнь жителей страны улучшается, сельская местность изменяет свой облик. Однако, по результатам исследования количество бедных семьей в деревнях остается высоким, особенно в горных, в удалённых районах. Разница между уровнем жизни и заработком деревенских и городских жителей увеличивается.

На основе Постановления премьер-министра Вьетнама под номером 124/QĐ-TTg от 02.02.2012 об утверждении Генерального плана развития сельскохозяственного производства на период до 2020 г. и видения на 2030 г., Постановления премьер-министра Вьетнама под но- мером 880/QĐ-TTg от 09.06.2014 об утверждении Генерального плана развития промышленности страны на период до 2020 г. и видения на 2030 г., в которых указывается, что большое внимание уделяется развитию сельскохозяйственной техники и оборудования, Министерство сельского хозяйства и развития села Вьетнама издало Постановление № 3642/QĐ-BNN-CB от 08.09.2015 [3] об утверждении Проекта усиления механизации сельского хозяйства для реструктуризации сельскохозяйственного производства. Этот документ помог активировать механизацию сельского хозяйства в соответствии с конкретными условиями каждого района, с характеристикой культивируемых растений и животных, особенно в районах концентрированного, товарного производства. Все это способствовало изменению старых методов хозяйствования, применению современной техники и оборудования, и как результат повышается производительность труда, качество продукции, эффективность производства, сокращаются потери в сельском производстве. Была поставлена цель поднять к 2020 г. средняя по стране энергооснащенность до 3-3,5 л.с/га. Средний уровень механизации областей выглядит следующим образом (табл).

Основные направления научно-технического развития в сельском хозяйстве Вьетнамa.

Для реализации целей и задач развития сельского хозяйства Вьетнама работы по исследова-

Таблица. Средний уровень механизации в сельском хозяйстве Вьетнама

\begin{tabular}{|l|c|c|c|}
\hline \multicolumn{1}{|c|}{ Образ производства } & ед. изм. & 2014 & 2020 \\
\cline { 3 - 4 } & & & \multicolumn{2}{c|}{ Год } \\
\hline 1. Растениеводство & & 90 & 95 \\
\hline Возделывание земли & $\%$ & 30 & 75 \\
\hline Посадка растений & $\%$ & 60 & 80 \\
\hline Уход & $\%$ & 90 & 95 \\
\hline Активное орошение & $\%$ & 42 & 80 \\
\hline Сборка (главным образом риса) & $\%$ & 40 & 80 \\
\hline Сушка зерна & $\%$ & & 70 \\
\hline 2. Животноводство & & 35 & 80 \\
\hline - Хлевы & $\%$ & 40 & 80 \\
\hline - Изготовление кормов & $\%$ & 45 & 85 \\
\hline - Дойка & $\%$ & & 80 \\
\hline 3. Производство соли & $\%$ & 50 & \\
\hline - Изготовление расспола & $\%$ & & \\
\hline - Собирание, транспорт & $\%$ & & \\
\hline
\end{tabular}


нию и применению достижений научно-технического прогресса в сельскохозяйственном производстве должны быть сосредоточены на следующие приоритетных направлениях:

а. Селекция и технологии растениеводства и животноводства

Достижения в этом направлении научно-технологического прогресса не требуют крупного капитала, но быстро дают высокую эффективность в производстве. Конкретно:

1. Селекция сортов и набора сортов растений с высокой урожайностью и высоким качеством, подходящих экологическим зонам, в соответствии с требованиями биологического разнообразия.

2. Селекция лучших сортов из имеющихся генетических ресурсов в стране и одновременно дальнейшее изучение с целью создания новых сортов растений и пород животных с хорошими генетическими характеристиками, подходящие Вьетнаму для выращивания и разведения. Например, сорта винограда, черешни, яблок, клубники из Европы, США, Австралии являются самыми популярными, которые имеют высокий спрос и стоимость.

3. Метизация, селекция новых сортов и пород в направлении:

- культуры с высокой производительностью, хорошим качеством, устойчивые к вредителям и болезням, особенно к пирикуляриозу и насекомым Nilaparvata lugens семейства «свинушки», для районов с особыми условиями, которые частор страдают от засухи, наводнения, наступления морской воды и т.д;

- особые сорта фруктов с высокой экспортной ценностью - манго, личи, лонган, драконий фрукт и других;

- домашние животные: постные свиньи, молочные коровы с высокой продуктивностью и плодовитостью, птицы на мясо и на яйцо;

- улучшение смешанных садов.

б. Исследования и применение достижений биотехнологий в производстве

Основными направлениями здесь являются:

1. Разработка и применение генных технологий: изучение и составление генофонда для описательной оценки специфических характеристик, составление молекулярной карты, хранение in vitro - в пробирке; исследование и применение генных технологий, технологий рекомбинантных ДНК (молекулярное клонирование ДНК in vitro для ввода в живые организмы животных или растений) для создания новых сортов и пород с заданными характеристиками [4. с.32]. Например, сорта риса, устойчивые к засолению, засухе, затоплению, гербицидам, болезням, с высокой урожайностью и т.д.

2. Исследование и применение технологий тканевой культуры и растительных клеток для обеспечения быстрого размножения и регенерации важных сортов растений.

3. Исследование и применение биотехнологий в создании новых пород животных. Следует обратить внимание на методы молекулярной генетики, генные технологии для создания новых пород, технологии гибридизации животных, технику трансплантации зигот, технику переноса гена гормона роста... Результаты исследований позволяют правильно выбрать среду для долгосрочного сохранения спермы, которая улучшает процесс технологии создания эмбрионов, перенос эмбрионов, замораживание эмбрионов свиней и коров in vitro. Методы искусственного осеменения позволяют увеличить все взрослых коров с 180 кг до 250-300 кг, объем мяса - в 1,5 раза. Крестьяне во многих районах также применяют биотехнологии для компостирования, изготовления кормов для животных и птиц, чтобы утилизировать сельскохозяйственные отходы и снижать производственные затраты.

4. Исследование и применение микробиологических технологий: для совершенствования технологий производства азотфиксирующих, фосфаторазлагающих удобрений, стимуляторов роста и т.д.; изучение грибковых, бактериальных, вирусных технологий и современных биохимических технологий; изучение биотехнологий для производства продуктов с богатыми питательными веществами, белком, витаминами; изучение ветеринарных препаратов; изучение и применение биотехнологий для сохранения и переработки сельскохозяйственной, лесной и рыбной продукции с целью сокращения потери после уборки. Биотехнологии должны помочь охране окружающей среды, особенно содействуют реализации программ лесопосадок, выращиванию деревьев на голых участках и холмах.

Согласно данным Министерства сельского хозяйства и развития деревни Вьетнама, в настоящее время на более чем 90\% площадей риса, 80\% площадей кукурузы, 60\% площадей сахарного тростника, 100\% площадей вновь поса- 
женных кешью применяются новые сорта, что увеличивает долю применения новых сортов в сельскохозяйственном производстве. Применение многих новых технологий способствует реструктуризации сельской экономики и села и увеличивает экспортную стоимость, в результате Вьетнам вошел в группу ведущих в мире экспортеров креветок, сомов, кофе, орехов кешью, черного перца и риса.

\section{с. Исследование технологий переработки сельхозпродукции}

Прежде всего, важно обратить внимание на следующие технологические направления:

- технологии до, во время и после уборки урожая, в первую очередь технологии сушки, особенно риса, кукурузы, маниока, кофе;

- технологии предварительной и окончательной переработки в подходящих масштабах видов сельхозпродукции, которые имеют высокие ценности для внутреннего и экспортных рынков;

- технологии сохранения сельхозпродукции, особенно свежих овощей и фруктов, чтобы продлить время использования и сохранить их качество.

Эти три приоритетных направления в изучении и передаче научно-технологических достижений в сельскохозяйственное производство для достижения целей и задач, поставленных на ближайшее время для сельского хозяйства Вьетнама [5]. Успешное выполнение этих задач будет способствовать повышению эффективности сельскохозяйственного производства и коммерции на основе повышения коэффициента полезности использования земли, роста урожайности и качества сельхозпродукции и одновременно будет создаваться новые рабочие места (для выращивания грибов, переработка сельхозпродукции...). Это должно привести к росту доходов и повышению уровня жизни крестьян. Наряду с этим необходимо уделить внимание следующим направлениям работы с целью всестороннего развития сельского хозяйства и села:

Первое, принятие мер по защите и эффективной эксплуатации земельных, водных и лесных ресурсов. В частности, обратить внимание на повышение плодородия угодий, ввод в оборот брошенных земель путем развития ирригационной системы, укрепления имеющихся и строительства новых ирригационных систем для предотвращения эрозии и применения сельскохозяйственной техники, соответствующей условиям каждого отдельного экологического региона, создания экономико-экологических хозяйств, где рационально сочетаются сельскохозяйственное, лесное и рыбное производство и охрана экологической среды, особенно в предгорных и горных районах.

Bторое, изучение инновационных технологий растениеводства и животноводства для каждого региона. В первую очередь, обратить внимание на применение научных решений для определения структуры урожая, структуры растений и животных, соответствующей каждому экологическому региону, применения комплексных технических мер для повышения производительности и защиты культур и животных в направлении интенсивного сельского хозяйства и товарного производства.

Tретье, механизация, электрификация сельского производства. Уделить внимание разработке, производству и внедрению в сельскохозяйственное производство машин и оборудования, подходящих условиям в каждом регионе в основном в небольших масштабах (в крестьянских хозяйствах) для постепенного повышения уровня механизации, электрификации сельского хозяйства на всех этапах производства: подготовка земель, выращивание, транспорт, орошение, уборка,... для достижения целей индустриализации и модернизации сельского хозяйства и села.

Четвертое, изучение ирригационных технологий для развития сельского хозяйства и села.

Научные исследования в области водного хозяйства в предстоящее время в основном сосредоточены на следующих направлениях:

1. Охрана, рациональная и эффективная эксплуатация водных ресурсов в увязке с охраной окружающей среды.

2. Борьба с наводнениями и облегчение стихийных бедствий, одновременно с изучением гидродинамики рек, прибрежных территорий, с надежной охраной системы речных и морских дамб и т.д. Завершение подготовки сценариев борьбы с наводнениями, с изменением русла рек, с паводками в горных районах, с затоплением в районах, часто страдающих от наводнения, а также наблюдение за влиянием крупных ГЭС на низовье рек.

3. Принятие мелиорационных мер для повышения плодородности земли, основным содержанием которых является решение проблем, связанных с водой и почвой и сельскохо- 
зяйственными культурами с целью получения сельскохозяйственных культур высокой урожайности, улучшения качества почвы для мощного развития сельского хозяйства.

4. Изучение научно-технических вопросов для строительства новых сооружений, совершенствование, обновление, переоборудование и модернизация существующих ирригационных объектов, эффективная эксплуатация и снижения стоимости их строительства.

5. Предложение мер по повышению эффективности ирригационной экономики.

Пятое, изучение научно-технических вопросов в области лесного хозяйства:

1. Продолжение селекционных работ, отбора, импорта, адаптации и быстрого размножения быстрорастущих лесных культур в соответствии с экологическим условиям каждого региона в рамках программы посадки 5 млн. га лесов до 2010 года. До 31/12/2016, Вьетнам имеет 14377682 гектаров леса [6].

2. Разработка технических норматив лесоразведения для каждого вида лесных культур, подходящих экологическим условиям каждого региона; технические нормативы создания защитных лесов, восстановление, планирование лесов и интенсивное проведение лесного хозяйства для повышения продуктивности.

3. Дальнейшее изучение, совершенствова- ние управления для успешной передачи земли и леса в введение крестьянских семей, с целью увязать интересы крестьян с охраной и развитием лесов.

4. Широкое распространение производственных моделей с применением биотехнологий по методам агролесомелиорации и земледелия на наклонных участках для повышения эффективности производства, объединение сельскохозяйственного производства с лесным хозяйством для охраны окружающей среды.

Шестое, изучение научно-технических вопросов в сфере рыбного хозяйства:

1. Дальнейшее изучение и развитие искусственного разведения креветок, пресноводных рыб, морских рыб и т.д. с высокими экономическими ценностями, чтобы не было проблем с приобретением малков и расширением производства; организация производства кормов для креветок, личинок креветок и мальков рыб для обеспечения высокой экономической эффективности.

2. Изучение профилактики и лечения заболеваний креветок и других водных животных; технические процессы культивирования водных организмов с обеспечением высокой экономической эффективностью и охраны экологической среды.

\section{Библиографический список}

1. Ассоциация фермеров Вьетнама. URL: http://mtnt.hoinongdan.org.vn/sitepages/news/1098/36380/hieu-quasu-dung-dat-nong-nghiep-tai-viet-nam-con-thap (дата обращения: 25.8.2015г)

2. Статистический ежегодник Вьетнама 2016 г.

3. Библиотека права онлайн. URL: https://thuvienphapluat.vn/van-ban/Linh-vuc-khac/Quyet-dinh-3642-QDBNN-CP-co-gioi-hoa-nong-nghiep-tao-dong-luc-tai-co-cau-nganh-nong-nghiep-2015-291246.аspх (дата обращения 10.2015г)

4. Решения для развития органического сельского хозяйства во Вьетнаме Хошимин. 2017.

5. Чан Мин Там. Сохранение и обработка послеуборочной сельскохозяйственной продукции. Ханой. 2012.

6. Коммунистическая партия Вьетнама онлайн-газета. URL: http://www.dangcongsan.vn/khuyen-nong-huongtoi-su-phat-trien-ben-vung/tin-tuc/dien-tich-trong-rung-7-thang-nam-2017-tang-so-voi-cung-ky-namtruoc-448779.html (дата обращения 4.8.2017г) 